\title{
SOCIOLOGICAL REVIEW OF THE PHENOMENON OF SPATIAL MOBILITY
}

Удк 316.444

DOI https://doi.org/10.32843/2663-

5208.2020.12-1.18

\section{Рyсcу Д.Е.}

аспірант кафредри соціології

Харківський національний університет імені В.Н. Каразіна

\begin{abstract}
Стаття присвячена аналізу просторових мобільностей та їхньому місцю в сучасному світі. Показано, що вони є одним з найважливіших елементів сучасної цивілізації. Мобільності - че переміщення у фрізичному просторі в їхньому зв'язку із соціальними відносинами. Також мобільності включають у себе елементи матеріальної інфраструктури, що забезпечують можливості для існування мобільності та всі характеристики певного суб'єкта, які дають змогу йому бути мобільним: різноманітні навички, рівень доходу, прагнення рухатися або бути осілим. Продемонстровано, що існування мобільності нині забезпечується сучасним рівнем розвитку технологій.

у статmі здійснено аналіз соціологічного осмислення концепцій мобільності таких авторів, як Г. Зіммель, З. Бауман, Ж. Дельоз, Ф. Гваттарі, М. Кастельс, Дж. Уррі. Проведено порівняння цих концепцій. Вони схожі в тому, що визнають сучасність нестабільною, хаотичною та мінливою. Продемонстровано, що в рамках такої мінливості мобільність стає однією з ключових рис сучасності та одночасно детермінантою соціальних змін. Нині саме мобільність забезпечує накопичення капіталів, трансорормацію культури та основу для соціальних відносин. Окрім того, мобільність змінюе сприйняття простору та часу. Фізичний простір сучасного світу підпорядкований потребам мобільності: світ охоплений сіттю автомобільних доріг, заправок, паркувань, мотелів і т.д.

Зроблено висновок, що, незважаючи на певні схожі риси соціологічних концепцій у сучасних соціальних науках відсутній консенсус щодо природи просторовоі мобільності. Це зумовлено складністю предмета дослідження. У зв'язку з цим запропоновано звернути увагу на необхідність його подальшої теоретичної концептуалізації. Результати дослідження можуть бути використані для поглиблення розуміння просторової мобільності та посприяти розвитку парадигми «нових мобільностей».
\end{abstract}

Ключові слова: соціальна мобільність, просторова мобільність, потоки, текуча сучасність, соціальний простір.

The article is devoted to the analysis of spatial mobilities and their place in contemporary world. It is shown that they are one of the most important elements of modern civilization. Mobility is movements in the physical space in their connection with social relations. Mobility also includes elements of material infrastructure that provide the opportunity for the existence of this mobility, as well as all the characteristics of a particular subject that allow him to be mobile: a variety of skills, income, and desire to move or be sedentary. It is demonstrated that the existence of mobility today is provided by the modern level of technological development.

The article analyzes the sociological understanding of mobility concepts of such authors as G. Simmel, Z. Bauman, G. Deleuze, F. Guattari, M. Castells, J. Urry. A comparative analysis of these concepts is also conducted. They are similar in that they recognize modernity as unstable, chaotic, and volatile. It is demonstrated that within the framework of such variability, mobility is becoming one of the key features of modernity, and at the same time a determinant of social change. Today mobility provides accumulation of capital, transformation of culture and the basis for social relations. In addition, mobility changes the perception of space and time. The physical space of the modern world is subordinated to the needs of mobility: the world is covered by a network of roads, gas stations, parking lots, motels, etc.

The conclusion is made that, despite some similar features of sociological concepts, there is no consensus on the nature of spatial mobility in modern social sciences due to the complexity of the subject of study. In this regard, it is proposed to pay attention to the need for its further theoretical conceptualization. The results of the study can be used to deepen understanding of spatial mobility and contribute to the development of the paradigm of "new mobility".

Key words: social mobility, spatial mobility, flows, liquid modernity, social space.
Сучасна цивілізація характеризується стрімкою технологізацією. Вона вплинула на всі сфери людського існування та призвела до низки значних змін у соціальному житті. Однією із таких змін стало зростання масштабів просторової мобільності. Завдяки розвитку засобів пересування та супутньої інфраструктури мобільність підпорядкувала собі простір та час. Нині все перебуває в постійному русі: люди, інформація, ідеї, культурні патерни. Це робить мобільність однією із ключових властивостей сучасності.

Разом із тим соціогуманітарні науки поки не знайшли вектор, по якому б розвивалися дослідження просторової мобільності. $€$ велика кількість різноманітних теорій, що зосереджують фокус своєї уваги на різних аспектах просторової мобільності. Таким чином, метою цієї статті є аналіз та підсумування концепцій просторової мобільності.

Мобільність, якщо розглядати її в широкому сенсі, - це здатність будь-якого об'єкта до швидкого пересування. У соціології термін «мобільність» уперше був використаний П. Сорокіним. Дослідник визначав її як переміщення людини не в географічному, а в соціальному просторі, який при цьому є ієрархічно структурованим. Тут ми маємо справу з так званою «соціальною мобільністю», яка передбачає переміщення людини з однієї соціальної 
страти в іншу. Вивчаючи такий вид мобільності, соціологи ігнорували реальні переміщення людей у фізичному просторі. Ця тенденція тривала приблизно до 70-х років XX ст., коли вони (переміщення) знайшли своє місце в соціології міста. Натепер виникає гостра необхідність у вивченні саме просторової мобільності, адже постійне зростання її масштабів $€$ одним з ключових процесів у сучасних суспільствах.

Цей процес включає в себе зростання мобільності не тільки людей, але й товарів, знань та інформації. Виникнення дискурсу масової мобільності в науковій літературі було узагальнено як «мобільний поворот». Він стосується як соціології, так й інших наук, таких як географія, статистика, міграційні дослідження та інші соціогуманітарні дисципліни. Дослідження свідчать про те, що нині півтора мільярда лише законних пасажирів щорічно куди-небудь прилітають, що означає чотири мільйони людей щодня; по Землі мандрує 40 мільйонів біженців; а ще є близько двох мільярдів автомобілів. Такі різноманітні та масштабні прояви сучасних мобільностей роблять тему цієї статті актуальною. Крім того, про актуальність дослідження свідчить і той факт, що транспорт - це джерело парникових газів, що постійно зростає. 3 огляду на підвищення числа пересувань автомобілями по всьому світі, збільшення кількості авіаперевезень і перевезень землею, є вкрай мала ймовірність того, що це зростання зупиниться. Окрім викидів парникових газів та забруднення повітря, воно має й інші негативні результати, що пов'язані з погіршенням екології та здоров'я людей: зростання шумових забруднень, виснаження озонового шару, а також численні медичні наслідки у вигляді травм, смертей, астми, ожиріння [1; 2]. Це свідчить про необхідність аналізу мобільності та подальшого пошуку альтернативних шляхів її реалізації.

Безпосередньо просторова мобільність це численні переміщення в їхньому зв'язку із соціальними відносинами в просторі і часі. Також сюди включаються всі характеристики такого суб'єкта, які дають йому можливість бути мобільним: певний рівень доходу, прагнення індивіда до постійного руху, соціальні умови доступу населення до наявних транспортних та телекомунікаційних систем, володіння тими чи іншими набутими навичками (наприклад, наявність освіти, водійських прав, знання міжнародної англійської мови) [3, с. 37].

Усі ці фактори роблять мобільність можливою та сприяють виникненню певних соціальних відносин. Вони є важливим фактором того, як суспільство сприймає та організує свій фізичний та соціальний простір. Залежно від того чи іншого типу концептуалізації мобіль- ності змінюються й характеристики цього простору. Так, наприклад, він може сприйматися як сукупність «місць», оскільки мобільність - це пересування з одного «місця» до іншого, а безпосередньо переміщення в цьому просторі можуть стосуватися як людей, так і матеріальних чи нематеріальних товарів, а також інформації. Звичайно, одиниці виміру варіюються залежно від того, що саме переміщується: це може бути, наприклад, кількість переміщених туристів за певний проміжок часу, кількість переміщених транспортних засобів, кількість тонн переміщеного товару. Зростання обсягів цих переміщень одночасно зумовлює розвиток мобільності та залежить від нього. Цей процес сприяє прискоренню темпів життя та збільшенню повсякденних операцій, які виконують люди [4].

Також цим процесам прямо або побічно сприяє швидкий розвиток технологій, зокрема інформаційних та комунікаційних. Дослідники підкреслюють, що саме у зв'язку зі значним поширенням таких технологій у сучасних суспільствах здійснюється й розвиток мобільності. Більш того, цей процес характеризується як одна з найбільш важливих соціальних трансформацій сучасності [5].

Незважаючи на важливість феномена мобільності для сучасної цивілізації, у соціогуманітарних науках поки не склалося єдиного чіткого уявлення про те, що саме розуміти під просторовою мобільністю та як розвивати подальші дослідження. Для опису просторової мобільності виникли численні поняття, що відображають її масштаб. Наприклад, нині науковці говорять про «кочові» або «мережеві» суспільства, про простір «потоків» чи «скейпів» [6, с. $112 ; 7$, с. 354]. Так чи інакше питань просторової мобільності у своїх роботах торкалися такі вчені, як Г. Зіммель, О. Дункан, П. Блау, Р. Парк, М. Шеллер, Б. Латур та ін., але вони так і не дійшли згоди.

Одні стверджують, що мобільність - це лише одна з багатьох рис суспільства, інші що мобільність - це ключова характеристика та детермінанта розвитку людства. Різноманіття підходів до вивчення просторової мобільності зумовлює мету цієї статті - проаналізувати й узагальнити досвід теоретичного осмислення сучасних мобільностей і виділити їхні основні компоненти.

Як було зазначено раніше, на просторову мобільність звернули особливу увагу в рамках соціології міста та урбанізації. Одним із перших це зробив німецький соціолог Г. Зіммель. Він зазначив, що просторові позиції людей та їхнє переміщення у фізичному просторі відіграють важливу роль у формуванні соціальних відносин: наприклад, під час подорожей виникає феномен так званої «співприсутності». Г. Зіммель стверджує, що можливість вільно 
переміщуватися в просторі являє одну з базових потреб людини. Ї̈̈ задоволення веде до підтримки соціального статусу індивіда. Таким чином, інтенсифікація міграційних процесів та просторової мобільності перетворюються на один з найважливіших соціальних ресурсів як індивідів, так і груп [8].

Деякі елементи ідей Г. Зіммеля згодом знайшли своє продовження в теоретизуванні соціологів «чиказької школи». У першій половині XX ст. вони провели низку досліджень мобільності, що були присвячені бродячому образу життя повій, банд, нелегальних мігрантів і т.д. [9, с. 29-41]. Ці дослідження проводилися в контексті інтенсифікації урбанізації.

У результаті такого інтересу чиказьких соціологів до впливу урбанізації на соціальне становище людини Р. Парк та Е. Берджес запропонували так звану «теорію соціальної екології», де вони спробували поєднати загальнобіологічні та соціальні закономірності розвитку суспільства. Згідно з цією теорією, просторове структурування людських переміщень підпорядковане «екологічному» порядку устрою життя того чи іншого індивіда. Автори пов'язують мобільність перш за все з деякими змінами, що відбуваються з людиною: зміна місця проживання, місця роботи та будь-яких місць, що мають те чи інше відношення до діяльності людини [10]. Тобто тут ідеться про міграцію. А міграція, згідно з цією теорією, $€$ основним показником та одночасно каталізатором соціальної мобільності [9, с. 55].

Проте дослідження мобільності чиказької школи не зайшли надто далеко, оскільки в соціології взяли гору «статичні» теорії: структурний функціоналізм, позитивістський аналіз і т.п. Вивчення мобільності перетворилося на аналіз, наприклад, транспорту та туризму як самостійних ізольованих галузей дослідження.

Основною думкою чиказьких соціологів з приводу мобільності було те, що вона характеризує міське життя. Саме хаотичний гарячковий рух, переміщення фізичних тіл у міському просторі $є$ найважливішою рисою сучасності. Таким чином, дослідники зробили акцент на тому, що мобільність - це не просто одна з характеристик навколишнього світу, але його ключовий компонент. Вона визначає соціальні відносини та конституює простір і його сприйняття людьми. Про важливість дослідження простору говорив також і 3. Бауман.

Питання простору для нього актуалізувалося із переходом від «важкої сучасності» до «легкої». Під «важкою сучасністю» дослідник розумів епохи, коли основною метою людства було активне привласнення та використання територій. Це зумовлено тим, що саме до простору був прив'язаний капітал, адже виробничі потужності та інші ресурси перебували безпосередньо в певній точці простору, а в умо- вах відсутності засобів для мобільності така ситуація робила простір вкрай цінним. «Легка сучасність», своєю чергою, характеризується тим, що територіальні обмеження для капіталу, людей та ідей відсутні. Сучасні засоби мобільності дають змогу здійснювати переміщення вельми оперативно, а системи зв'язку та Інтернет дають можливість керувати будьякими операціями віддалено, що не потребує присутності людини в певний час у певному місці. Згідно з цією теорією виникає замкнуте коло: для здійснення мобільності необхідний капітал, а для здобуття капіталу - мобільність. Водночас мобільність $€$ доступною далеко не кожній страті населення [11, с. 7-23].

Також 3. Бауман розробляє та концептуалізує деякі широко використовувані нині соціологічні терміни. Так, «бродяга» - це паломник без пункту призначення, для нього характерна неможливість перебувати на одному місці, вічне хаотичне переміщення. «Туристу» властиве організоване переміщення 3 подальшим нав'язуванням відвідуваним місцевостям власних смислів. «Кочівник» чинить осмислений опір культурним кодам і поступальне переміщення, символ розмивання центру. Крім того, є також похідні від цих понять метафори: «суспільство кочівників», «кочова свідомість» і т.д. Подібні прийоми необхідні для того, щоб характеризувати певний стан індивідів, якому притаманне прагнення до детериторіалізації простору за допомогою якомога ширшої мобільності. Цей процес у сумі з глобалізаційними тенденціями актуалізує проблему транснаціонального світового громадянства [12].

Отже, як і Г. Зіммель, З. Бауман говорить про те, що мобільність $€$ не просто рисою того чи іншого суспільства, а тим, що визначає його соціальні відносини в умовах «легкої сучасності». Однак якщо Г. Зіммель робить упор на аналізі наслідків мобільності для окремо взятої людини в умовах міського простору, то 3. Бауман теоретизує на глобальному рівні. Він стверджує, що відбувся перехід від важкої твердої сучасності до легкої рідкої, де головну роль відіграє швидкість руху людей, грошей, паломників, туристів, образів та інформації, які конституюють простір. Така сучасність характеризується невизначеністю та хаотичністю.

Хаотичною сучасність $€$ також для французьких філософів Ж. Дельоза і Ф. Гваттарі, які розробили концепцію номадології. Автори вказують основними характеристиками сучасного життя його кризисність, хаотичність, мінливість. Які З. Бауман, вони пропонують власну модель глобального суспільства. Для ілюстрації для такої моделі дослідники використовують образ «різоми». Різома - це кореневище, що розповзається в різні боки. У нього відсутній центр, воно нагадує грибницю, а тому його неможливо знищити. Згідно з філософами як 
людина, так і суспільство, і культура завжди мінливі. Вони ніколи не зможуть сформуватися до кінця, отже, завжди перебувають у процесі становлення. Мобільність індивіда в умовах суспільства, що постійно переформується, ґрунтується на принципі включеного руху. Тут Ж. Дельоз та Ф. Гваттарі проводять аналогію з бурхливим потоком ріки, в якому знаходяться люди замість того, щоб спостерігати за ним із берега. Відповідно до цієї теорії мобільність у сучасному глобальному суспільстві не примха чи привілей. Виживає тільки мобільний, і мобільність стає свого роду аналогом природного відбору [13]. Тут ми спостерігаємо певні паралелі з концепціями авторів, розглянутих раніше. Мобільність виступає ключовим компонентом сучасного суспільства, підставою для побудови його певної моделі. Соціальні відносини такого суспільства зумовлені саме мобільністю.

На чільне місце соціології просторова мобільність була поставлена вже в 1980-х роках, коли стався «просторовий поворот» у соціальних науках. Сюди включаються теорії та дослідження, які демонструють, що соціальні відносини просторово організовані та що просторове структурування істотно впливає на ці соціальні відносини [14].

Так, наприклад, М. Кастельс висуває гіпотезу про те, що в сучасному суспільстві («мережевому», як його називає автор) простір і час трансформуються під впливом інформаційно-технологічного розвитку, в результаті чого виникає нова просторова логістика, що дістає назву «простір потоків».

Потоки - це повторювані, цілеспрямовані та конструйовані послідовності обмінів і взаємодій між фізично роз'єднаними позиціями різноманітних суспільних структур, які займають соціальні актори. Тобто саме фізична інфраструктура та зумовлені нею мобільності дають змогу конструювати певний тип простору. М. Кастельс приділяє набагато більше уваги власне просторовому питанню, аніж 3. Бауман, про якого ми говорили раніше: іспанця цікавить те, які саме простори роблять можливим існування в суспільстві поляризованих класів. Він виходить з того, що простір - суть, матеріальна основа, «оснащення» для протікання соціальних практик. Більше того, М. Кастельс, як і 3. Бауман (у якого теж можна знайти схожі судження), вважає, що в капіталістичному суспільстві саме простір організовує час. Інакше кажучи, ті нові практики та форми взаємодії, які нерідко називають прискоренням соціального часу, можливі лише остільки, оскільки для цих форм існує матеріальна, просторова основа та інфраструктура [7, с. 385].

Тобто простір і мобільність тут є вже не просто підставою для здійснення тих чи інших соці- альних взаємодій. Вони стають необхідною умовою таких взаємодій. Взаємна зумовленість фізичного та соціального просторів знаходить своє відображення і в роботах англійського соціолога Дж. Уррі. У своєму теоретизуванні він так чи інакше спирався на праці описаних нами раніше дослідників. Так, наприклад, мобільність у концепції Дж. Уррі, як і у М. Кастельса, здійснюється через потоки. Однак англієць, на відміну від іспанця, бачив їх хаотичними та неупорядкованими. Також він розвиває ідеї «чистої інтеракції», спілкування заради спілкування та «співприсутності» Г. Зіммеля.

Дж. Уррі поставив собі за мету аналіз мобільності загалом. Саме Дж. Уррі $є$ автором поняття «мобільний поворот» у соціогуманітарних науках. Цей підхід зосереджується на тому, що соціальне, культурне та економічне життя суспільств організується різноманітними видами переміщень, комунікацій та транспортування. Основною тезою дослідника $є$ те, що суспільства повинні розглядатися саме через мобільність з тієї причини, що соціальне життя процесуальне, а тому неможливо досліджувати його в рамках статичних парадигм.

В основі парадигми нових мобільностей лежить концепт мережевого капіталу (або ж «капіталу рухливості»). Цей капітал складається із можливості людини будувати та відтворювати ті чи інші соціальні відносини та отримувати від них певні вигоди: фінансові, практичні, емоційні тощо. При цьому позиції людей, що перебувають у таких відносинах, можуть бути географічно віддалені. Тут можна провести паралелі з концепцією «простору потоків» М. Кастельса. Накопиченню «мережевого капіталу» сприяють певні типи мобільностей, що забезпечують можливість взаємодії на відстані: транспортування тих чи інших об'єктів чи активів, тілесні переміщення людей, віртуальні подорожі, комунікація, переміщення ідей тощо.

Дж. Уррі показує, що феномен мобільності стає вкрай неоднозначним та складним. Прикладом такої складної мобільності може служити явище «дауншифтінгу», що виникло в XX ст. та набирає популярності останнім часом. Дауншифтінг - це система поглядів, яка полягає у відмові від матеріальних цінностей, що нав'язуються суспільством споживання. Вона передбачає добровільне виключення індивіда із капіталістичної системи та прагнення знаходити власні цілі та досягати їх. Відкидаються цінності кар'єрного росту, високої зарплатні, соціального статусу, нескінченного споживання товарів масового виробництва та самоідентифікації на основі всього цього. Важливою частиною дауншифтінгу є відмова людини від місця свого проживання та переїзд подалі від мегаполісів, часто до такого місця, де майже відсутні люди. У соціологічних тер- 
мінах дауншифтінг можна інтерпретувати як спадну соціальну мобільність індивіда, здійснену за його власним бажанням. Він являє собою одночасно просторову та соціальну мобільність, горизонтальну та вертикальну. Він демонструє, як добровільна територіальна мобільність слугує для вирішення проблем, що пов'язані з вимушеною соціальною мобільністю. Отже, мобільність у просторі важлива як спосіб уникнути соціальної нерівності та виключитися з певної системи. Окрім цього її аспекту, Дж. Уррі розглядає цінність мобільності як такої. Дослідник виділяє дванадцять видів такої мобільності: пізнавально-екскурсійний туризм; ділові та професійні подорожі; пересування з метою знайти політичний притулок або місце проживання; рекреаційні поїздки; мобільність, що пов'язана з військовою повинністю; пенсійний туризм; міграція певної діаспори; рух працівників сфери обслуговування; «буксирні подорожі» дітей, родичів і слуг; відвідування друзів і родичів і переміщення, пов'язані з роботою [15, с. 80].

Отже, «мобільний поворот» робить наріжним каменем соціології подорожі та різноманітні переміщення в географічному просторі. Ці теорії беруть свій початок у соціології міста, а тому деякі риси цієї парадигми переносяться і на сучасний глобальний світ (наприклад, все та ж «співприсутність» Г. Зіммеля). І це не дивно, адже мобільність типового городянина століття тому та мобільність сучасної людини багато в чому схожі. Як для урбанізації, так і для глобалізації характерна інтенсифікація саме просторових переміщень людей, об'єктів та ідей у фізичному просторі. Просторова мобільність важлива не тільки сама по собі, а й у зв'язку 3 тим, як вона впливає на навколишній світ. Мобільність та навколишнє середовище перебувають у діалектичному зв'язку, вони опосередковують одне одного. Мобільність можлива завдяки фізичному простору, але й цей простір підпорядкований потребам мобільності.

Величезні простори нашої планети охоплені незліченними об'єктами транспортної інфраструктури: парковками, автомобільними трасами, станціями технічного обслуговування, постами дорожньої поліції, заправками, мотелями, аеропортами, зупинками, пристанями. Навіть саме небо поділено на повітряні льотні зони, що мають власні кордони та закони функціонування. Безліч людей задіяні як у виробництві, дистрибуції, обслуговуванні транспортних засобів, так і у підтримці всієї інфраструктури, що пов'язана з ними. Мобільне суспільство складається із цілої вкрай складної системи взаємозв'язків простору; місць, що наявні в цьому просторі; індивідів; інфраструктури та різноманітних технічних засобів; економіки; культури. Всі вони перебувають у непереривній взаємодії, яка змінює сприйняття простору та часу: зараз завдяки Інтернету нам досить кількох секунд, щоб зв'язатися із людиною, що перебуває на іншому континенті. А існування такої віртуальної мобільності було б неможливим без реальної фізичної мобільності комп'ютерів, серверів, кабелів і т.д. Таким чином, сучасний світ зробив можливим існування дуже великої кількості переміщень. Вони характерні для кожного з аспектів існування людської цивілізації: від економіки до культури.

Просторова мобільність також пов'язана із соціальною мобільністю, вона впливає на різноманітні середовища життя тих чи інших суспільств, вона змінює ці середовища. Разом із тим окремі об'єкти простору, й окремі люди, й культурні патерни самі по собі стають предметами мобільності. Тобто просторова мобільність давно стала чимось більшим, аніж просто переміщенням людини з однієї точки фізичного світу до іншої. Вона перетворилася на структурний елемент людського життя, що опосередковує нове відношення до простору та часу, їхню нову конфігурацію.

Незважаючи на таку важливу роль просторової мобільності для сьогоднішнього світу, сучасні соціогуманітарні науки поки не дійшли єдиної чіткої точки зору щодо їхньої ідентифікації. Мобільність у фізичному та, відповідно, в соціальному просторі стали дуже складними феноменами. Для їхнього аналізу необхідна система настільки ж складної операціоналізації, адже перш за все нам необхідно ідентифікувати те чи інше явище і тільки потім описувати його та проводити подальші дослідження. А ідентифікація можлива тільки через спостереження та копітку теоретичну роботу.

Якщо ми хочемо осмислити просторові мобільності в усій їхній складності, нам необхідно продовжувати розвивати «парадигму нових мобільностей», яка б остаточно стала підходом, що не просто розглядає територіальні конструкції як суми кордонів, співіснуючих у безперервному просторі, а зосереджується на аналізі цього простору в термінах відносин, які пов'язують і поєднують місця, розподілені фізичним простором, але поєднані простором соціальним, що можливе саме завдяки існуванню просторової мобільності.

\section{ЛITEPATУРA:}

1. Cresswell T. Mobilities I: Catching up. Progress in Human Geography. 2011. No. 35(4). Pp. 550-558.

2. Faist T. The mobility turn: A new paradigm for the social sciences? Ethnic and Racial Studies. 2013. No. 36. Pp. 1637-1646.

3. Kaufmann V. Re-thinking mobility. London : Routledge, 2002. 120 p.

4. Kaufmann V., Bergman M.M., \& Joye D. Motility: Mobility as capital. International Journal of Urban and Regional Research. 2004. No. 28(4). Pp. 745-756. 


\section{ГАБІТУС}

5. Green N. On the move: Technology, mobility, and the mediation of social time and space. The Information Society. 2002. No. 18(4). Рp. 281-292.

6. Бауман 3. Глобализация. Последствия для человека и общества. Москва, 2004. 188 с.

7. Кастельс М. Информационная эпоха: экономика, общество и культура. Москва, 2000. 608 с.

8. Зиммель Г. Большие города и духовная жизнь. Логос. 2002. № 34. С. 23-34.

9. Park R., Burgess E., McKenzie R. The City. Chicago : University of Chicago Press, 1925. 127 p.

10. Парк Р. Экология человека. Теория общества. Фундаментальные проблемы. 1999. С. 384-401.
11. Бауман 3. Текучая современность. СанктПетербург, 2008. 240 с.

12. Бауман 3. От паломника к туристу. Социологический журнал. 1995. № 4. С. 133-154.

13. Делез Ж., Гваттари Ф. Машина войны. Трактат о номадологии. Новый Круг. 2005. № 2-92. C. 183-187.

14. Ло Дж. Объекты и пространства. Социологическое обозрение. 2006. № 1. С. 30-42. URL: https://sociologica.hse.ru/data/2011/03/14/1211452463/ 5_1_6.pdf (дата звернення: 23.04.2020).

15. Урри Дж. Мобильности. Москва : Праксис, 2012. 576 c. 